Per Bjørnar Grande

Bergen University College, Norway

\title{
THE LOMANS' PRIVATE APOCALYPSE IN DEATH OF A SALESMAN
}

\author{
Therefore, \\ Their sons grow suicidally beautiful \\ At the beginning of October \\ And gallop terribly against each other's bodies
}

James Wright (1927-1980)

\section{Being well liked}

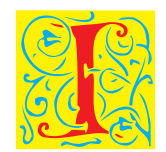

$\mathrm{n}$ the book entitled The American Dream. A Short History of an Idea That Shaped a Nation, Jim Cullen focuses on what he considers the six main themes according to which the American Dream is characterized: religious freedom, the quest for equality, the Declaration of Independence, upward mobility, home ownership, and fame and fortune. ${ }^{1}$ Arthur Miller's Death of a Salesman depicts a distorted version of this Dream. The first three of Cullen's themes do not play a central role in Death of a Salesman. However, the last three, upward mobility, home ownership, and especially fame and fortune, are core "values" for the Lomans, the family at the center of Miller's drama. In the light of the dream, we understand why the house and car are so important in the play. Even more significant, though, the central character Willy Loman's approach to life verges on a decayed version of the American Dream, in which talent and hard work are subordinated to fame. This modern delusion, in which a charismatic personality is a necessity, in which physical beauty is

1 J. Cullen, The American Dream. A Short History of an Idea That Shaped a Nation, New York: Oxford UP., 2003, 8. 
almost valued more highly than wealth, and in which the elected are those who do not have to try too hard, ${ }^{2}$ contains the elements of Willy's American Dream.

Willy Loman has no past, no tradition to cling to. He is a prisoner of the here and now. The cheapness of his existence is highlighted by the lack of tradition and history. To cope with this void, he only allows himself to see the world through the rose-tinted ideals and slightly brutal work ethics of a salesman. In the course of the play, the meaninglessness of the life of a salesman, once something outwardly able to fill his life with meaning, is gradually revealed.

In the play, Willy confesses to an imaginary Ben that he feels - kind of contemporary about himself. ${ }^{3}$ As a child, he was abandoned by his father. Lacking a father figure, he turned to his older brother, Ben, who did not really care about his younger brother, only his own career and success, a success partly based on cheating others. Like Jay Gatsby, Ben has taken short cuts on the road to success and wealth. Thus, Willy's basic male models from early childhood were people like his father, who abandoned him, and Ben, who was driven by a brutal desire for success. Willy is totally spellbound by Ben and his success, and, therefore, totally spellbound by the American Dream - without ever considering the premises or the futility of the dream.

Willy's background hints not so much at why he does not succeed in business, as at why he deceives himself and his family. His past has made him vulnerable to the outward trappings of the American Dream. Not once do we hear Willy Loman reflect on the reality of the dream, on the fact that there will be very few winners and very many losers. According to Brian Parker, Willy and his family are victims of the deterioration of this dream. Parker sees Willy's philosophy as a reflection of the personality cult of Dale Carnegie in which one wins friends and influences others for the purpose of gain. ${ }^{4}$

Willy thinks of himself in terms of what he does; his identity lies in his work title. He is not interested in who he really is or his inner value. His life philosophy focuses on success, primarily in sports and business. He has no other ideals, no religion or philosophy, to balance such an ideal. Willy thinks that, if he is not successful, he cannot deserve to be loved by his family. ${ }^{5}$ All

\section{Ibidem, 177-178.}

3 A. Miller, Death of a Salesman, London: Penguin Classics, 2000, 40.

4 B. Parker, "Point of View in Arthur Miller's Death of a Salesman," in: R. W. Corrigan (ed.), Arthur Miller. A Collection of Critical Essays (Twentieth Century Views), Englewood Cliffs, NJ.: Prentice-Hall, Inc., 1969, 102.

5 Bloom's Guides. Arthur Miller's Death of a Salesman, Chelsea House Publishers, 2004, 8. 
his life, he has compensated for his unhappy childhood by clinging to the belief that being popular is everything that is necessary. Willy believes in the cult of personality, and in the importance of charm. His dream of being successful in business and sport, as in other areas of life, is clearly based on the romantic and virility-based notion that one can make one's mark by outdoing others. Willy believes in the romantic personality, the person who is gifted by nature, who is looked up to and admired by others, and who does not have to work hard to attain success.

In Willy's view, natural strength and natural charm are enough, and he believes that these qualities are exactly what Biff has. Willy sees in Biff a kind of internalized superiority, evident is such statements as: "You got greatness in you." (Death of a Salesman, 53.) He just cannot understand that his son is lost "in the greatest country in the world" since he is a young man with such - "personal attractiveness."

Looks are clearly important. Biff is described as a young Hercules, ${ }^{7}$ while both boys are called Adonises. In his father's eyes, Biff stands above the normal moral limitations because of his looks and talent in sports; the fact that he breaks the rules simply highlights his superiority. Thus, Willy laughs proudly when Biff is accused of theft, and claims that if anyone else had stolen something, there would have been an uproar. ${ }^{8}$ While the young Biff, like Hercules with a golden helmet, is glorified by his father as a young god: "And the sun, the sun all around him" (Death of a Salesman, 54), he returns to his parent's home as a 34-year-old misfit. The strong, ruthless high-school graduate, with the looks of Adonis, has striven in accordance with his father and uncle Ben's law of the jungle, but has not been able hold down a job.

Willy has taught his sons the shortcut to success: success begins by being popular. If you are liked, you are not even obliged to abide by the law. Therefore Willy accepts that the young Biff steals timber and basketballs, not understanding that this ethical laissez faire attitude could later cultivate arrogance, laziness and ruthlessness. Justified by his brother Ben's law of the jungle, Willy accepts that there will be a certain dishonesty among the elect, the likeable, as an indication of superiority.

Willy, although hard working himself, does not convey to his sons that hard work is the real way to success. Blinded by his narcissism, he cannot see

\footnotetext{
${ }^{6}$ A. Miller, Death of a Salesman, London: Penguin Classics, 2000, 11.

7 Ibidem, 54.

8 Ibidem, 23.
} 
that education, which he lacks, could contribute to his sons' success. Moreover, by emphasizing personality and sport to such a degree, Willy actually limits his sons' chances for success.

\section{The American dream}

The more Willy tries to enhance his sons' success, the more they are channeled into failure. Willy's American Dream consists only of success, not of the hard work which is a prerequisite for success. Willy has become like Ben, inclined to take short cuts in order to attain his goal; but, unlike his brother, his desire for success ends in failure.

This causes readers to question the dream itself. According to Cullen, the real problem with the American Dream is that it is too incomplete a vessel to contain the longings that elude human expression or comprehension: "We never reach the Coast we think we see." (The American Dream, 182.) Thus, it is something related to the desires behind the dream which causes the dream to turn sour.

If we examine the models who have represented this mighty dream, Willy seems to have been influenced by the ideals of such men as Andrew Jackson, America's president from 1829 to 1837 , who was born poor, lived in near wilderness, and became successful due to his own strength and iron will. From this perspective, Ben becomes, in Willy's eyes, the ultimate living model for his sons to imitate.

However, there is one essential ingredient lacking in Willy's American Dream: He does not really believe in self-improvement, but rather in natural charisma. In this respect Willy, like Jefferson for example, thinks that there is a natural aristocracy among men based on talent. While this is part of the American Dream, it is clearly a distorted version, which, when combined with rivalry and ethical laissez faire, will pave the way for tragedy.

\section{Rivalry between father and son}

Willy's relationship with his son Biff turns from mutual admiration to mutual spite. Already before Willy and Biff begin to talk to each other on Biff's return, Willy is so obsessed with Biff that he is in a constant conversation with 
him, even though he is not there. The "dialogue" constantly switches between the here and now, and the past. It is both somber and idealistic, and Willy is constantly contradicting himself. In the same sentence, he refers to Biff as lazy and not lazy, ${ }^{9}$ revealing Willy's mental decline. Their unfulfilled relationship has, in Willy's case, developed into a loss of reality. When Biff finally enters the stage, Willy's wife Linda tells him that when Biff is at home, Willy is always at his worst. The closer Biff comes, the shakier his father becomes.

The conflict between Willy and Biff is clearly destined to end in tragedy. "Double mediation," René Girard's term for reciprocal imitation, between father and son arises because each of them desires success through the other. But in both cases, the desire for success turns into degrading failure and they begin to blame each other. Willy shifts continuously between praising and despising Biff. He can only accept the successful side of his son, a side which is constantly waning. Because Biff is a part of himself, he cannot accept anything but success. However, the pressure being put on Biff causes him to fail repeatedly. In one sense, his failure, like his father's, comes down to a deep desire to subvert the other's desire. Biff cannot succeed since that would mean that he has, existentially, become a fake like his father. Willy and Biff have become each other's stumbling blocks. Biff, however, has partially perceived this illusion, but instead of feeling sorry for his father, he considers him pathetic.

The previous time Biff had come home, Willy had thrown him out because Biff called him a fake. ${ }^{10}$ Biff swears to his mother that this time he will behave, ${ }^{11}$ but when Willy enters the room, they immediately begin blaming each other. The presence of Biff brings forth the demons in Willy - and likewise in Biff. The father and son have become obsessed with each other. The intensity of Willy's desire for success is so powerful that, when Biff returns home, he gradually begins to long for the same success. After only a day, despite the conflict and spite, Biff's belief in his father's unending ideal of success in business is renewed, and he forgets his hard earned insight into the illusion of his father's salesman-ideology. The fixation is so strong and demonic that Willy hardly notices that Happy is present. Even Linda, their mother, is caught up in the conflict between her husband and eldest son to such an extent that she does not react when Happy proclaims the good news that he is getting married. ${ }^{12}$

\footnotetext{
9 Ibidem, 11.

10 Ibidem, 43.

11 Ibidem, 47.

12 Ibidem, 53.
} 


\section{A distorted Oedipus complex}

It would not be unreasonable to call the relationship between Biff, Linda and Willy a distorted Oedipus complex. It has developed into a triangular pattern of desire in which father and son seemingly do not desire the mother but worldly success. This created a configuration in which the mother, Linda, always takes the side of the father. She does not know about her husband's infidelity, so she does not know that Biff is unconsciously defending her and punishing Willy for having betrayed her.

Biff does not only witness Willy in bed with a young lady, but he also discovers that Willy has given his lover stockings belonging to Biff's own mother ${ }^{13}$ - a very prestigious item after WW2. Thus, stockings become a symbol of Willy's betrayal, and in the play Willy cannot stand the sight of his wife mending her stockings.

The rivalry is enhanced by Willy's sense of guilt towards Biff. Every time Willy looks at Biff, he is reminded of his infidelity and he immediately feels exposed. After Biff witnesses Willy's affair in a hotel room in Baltimore, their relationship is irretrievably ruined. Both men live with this secret. Willy is terrified that Biff will expose him, and, at the same time, is guilt ridden. Every time Willy encounters Biff, he feels guilty and this makes him behave irrationally.

The hotel incident is often considered to be the key to Loman family's dysfunctional behavior. The scenes before the hotel-room scene build up neatly towards an unavoidable rivalry between father and son. Willy has, up to this incident, been the young Biffs main role model, and the boy believes blindly in his father's ideals, ideals which in substance may - if there is no outer goal, no enemy to conquer, and no jungle to escape to - create extreme rivalry. Rivalry between the father and son, however, is usually more complex than, for example, rivalry between friends and colleagues because it usually supplants by metamorphosis of a deep love; thus, love and loyalty are transformed into spite due to an identification crisis, and friendship is transformed into enemy twins.

This distortion of the truth results in Linda blaming Biff for Willy's attempted suicide. At this point, the play develops from a tale of domestic conflicts to a tragedy. As in the case of Oedipus Rex, this happens because vital information is withheld. Oedipus has no knowledge of who his real parents are, while Linda has no knowledge of having been deceived.

\footnotetext{
13 Ibidem, 95.
} 
Although the father-son relationship is complex, the system of desire is basically the same as in other relations. From such a perspective, the Oedipus complex is not an adequate model because it is a pre-constructed model, while desire is governed by no other model than the other's desire. According to René Girard, all desires are mimetic and based on the other's desire. It is therefore essential that the father is capable of eliminating potential rivalry before it becomes real and endangers family relations. Biff has lost faith in his prime imitative model and does not seem able to find an alternative. On the one hand, he hates his father and, on the other hand, he embraces his father's ideals of success, and this creates a double bind that leads to failure. Every time Biff attempts to succeed in business, he is reminded of his father's betrayal, and he subconsciously sets himself up to fail.

Seen through the lens of imitative desire, the play becomes a drama about liberation from the other. However, the play's fundamental insight, its genius, is its description of how desire works. Miller describes desire in such a way that it is only concerned with the unfulfilled. Desire has turned Willy and Biff into a state where everyday reality means less and less. They are possessed by each other. Even when Biff is not at home, Willy is still preoccupied with the conflict with his son, and the tragedy lies in the fact that Willy will not alter his belief in personality and success. As spectators, the audience follows Willy through the last 24 hours of his life in which the world is gradually closing in on him.

\section{Salvation in nature}

Death of a Salesman is based on a dark world-view. There seems to be no escape and no reconciliation possible within the frame of the characters' lives. Rivalry and conflict color the characters' outlook on life. While there is always a glimpse of freedom lurking around the corner, this is always destroyed by desire. The vitality of outdoor life is clearly an ideal for the characters. This is evident in Biff's claim that his family should be working on the land, out in the open air. Similarly, Willy admires the countryside from the road and feels claustrophobic in the mechanized urban environment. ${ }^{14} \mathrm{He}$ talks longingly of nature, the country and the open-air. Biff is even more frank about his yearning for a healthy life in the country: "We should be mixing cement on open plain - or carpenters. A carpenter is allowed to whistle" (Death of a Salesman, 48). Willy has, in Biff especially,

\footnotetext{
${ }^{14}$ R. Hayman, Arthur Miller, Contemporary Playwrights, London: Heineman, 1977, 30.
} 
nurtured an intense desire for freedom, which cannot be combined with life as a businessman. However, the possibility of living a simple, healthy and fulfilling life is destroyed by Willy's idea of success. The very idea of working with one's hands, which is clearly Willy's strength, is dismissed as being beneath the Lomans. Willy's snobbery is revealed when he categorically states that it is not good enough to work as a carpenter. ${ }^{15}$ This snobbery seems to be the result of rivalry.

Members of the Loman family are strong and healthy, and yearn for the outdoor life. Both Willy and Biff's real talents lie in outdoor work, using their hands, and their lives would probably not have been tragic if they had become carpenters and farmers. However, because of his ongoing rivalry with Biff, Willy is blinded and can't accept success in any field other than his own - as a salesman. Rivalry with his eldest son causes him to ignore his real desires, and he can't accept anyone else striving for these. Instead, he claims that success in business and sport are what really counts. Only when he is alone with Linda does he admit to yearning for the country and life as a farmer.

\section{The waste land of contemporary culture}

In his description of the drabness of life in the Loman family, Miller is touching upon the barrenness of modern life. Like T.S. Eliot's poem, The Waste Land, ${ }^{16}$ Death of a Salesman depicts contemporary Western urban culture as sterile and lifeless, a place where people are obsessed with novelty. However, in Eliot's poem, contemporary trends and materialism are echoed by a richer and more fertile past; beneath the cultural barrenness there lie seeds of moral regeneration. This indicated regeneration is also evident in Death of a Salesman, in Act Two, when Willy wants to go out and buy some seeds, and see things growing again. But according to Linda "nothing'll grow any more". (Death of a Salesman, 40) As in The Waste Land, growth is associated with cruelty. For example, April, the month of fertility, is the cruelest of all months, "breeding Lilacs out of dead land". (The Waste Land, lines 1-2) In Death of a Salesman, Willy experiences a similar barrenness, the same cruelty, claiming that "there is not a breath of fresh air in the neighborhood. The grass don't grow any more, you can't raise a carrot in the backyard". (Death of a Salesman, 12) The earth, in Death

\footnotetext{
15 A. Miller, Death of a Salesman, London: Penguin Classics, 2000, 48.

16 T. S. Eliot, "The Waste Land," in: T.S. Eliot. Collected Poems 1909-1962, London: Faber \& Faber, 1983, 61-86.
} 
of a Salesman, refers more concretely to the earth as such, but in both the poem and the play, barrenness seems to be the result of desire. According to Eliot, one finds, under the dry earth, traits of violence, hidden by hysterical and empty expressions of contemporary culture. Beneath the contemporary shallowness, the poem alludes to sacrifice; dead corpses and dry bones which dogs threaten to dig up again (The Waste Land, lines 69-76). In both the play and the poem, the decline of earth and culture are viewed as a unit, mixed up with death.

\section{Infidelity and barrenness}

The barrenness of existence gradually reveals itself, not as a lack of contact with nature, but as cruelty in human relations. In both The Waste Land and in Death of a Salesman infidelity seems to be a source of cultural emptiness. The low life of a salesman, which is the basic setting in Miller's play, is also evident in Eliot's poem. Mr. Eugenidies, the Smyrna merchant, becomes a symbol of the cultural decay (The Waste land, lines 208-214). Like Willy Loman, Mr. Eugenidies is loud, vulgar and contemporary. The currants in his pocket are a symbol of his utilitarian world-view based on physical nutrition. The decay of manners and morals are further emphasized by the small house agent clerk with staring eyes: "One of the low on whom assurance sits/ As a silk hat on a Bradford millionaire" (The Waste Land, lines 233-234). The house agent, a salesman like Willy, is vulgar, and his attempt to seduce is devoid of tenderness. His only purpose is physical self-satisfaction. The somber modernism as shown in these works, reveals, at its heart, a broken trust between man and woman.

While Willy clings to his shallow ideals of being liked and successful, and teaches his son to cash in on his personal attractiveness, the characters in The Waste Land, delve into vulgarity, the 'Jug Jug to dirty ears' (The Waste Land, line 103) where tradition is lost and replaced by horoscopes and loveless sexuality, causing indifference and the lack of communication.

\section{Sources to regeneration}

In Eliot's Waste Land experience is reconciliation, some sort of hope of continuation through the renewal of genuine European cultural values. Intertextuality of the poem creates a dialectic between a rich past and a barren 
contemporary world. The hopelessness of the here and now, however, is not absolute. It is debased but has, nevertheless, evolved from a rich and fertile past. The Waste Land ends with images from an ancient religious and literary tradition which promotes fertility and peace, indicating a future of regeneration and reconciliation.

In contrast, the characters in Death of a Salesman lack a cultural heritage, myths or religion. The Loman family is lost in their distorted American dream, with no reinvigorating ideas or ideals to help them find a better existence. The desire to move out into the countryside is clearly an ideal, but can never be materialized because of the rivalry between father and son. The freedom to break out, start anew, and do something they really enjoy, can only be realized if the characters give up their current existence in which the real objects of desire constantly vanish due to the fierce father-son rivalry. This rivalry has become so complex that Willy would actually never be able to be reconciled with it. In their enclosed suburban Brooklyn environment, there is no reinvigorating past and no invigorating future. Their world is a closed world because they have, in their own eyes and those of others, become losers in their competition to succeed.

After the disastrous dinner at the restaurant, Willy tries one last time to get hold of some seeds to plant. ${ }^{17}$ The desire to see something to grow comes after the father and son have revealed their personal drought; Willy has been fired and Biff has run out of a job-interview after stealing a fountain pen. The seeds represent Willy's last hope. They seem to be the nearest the play gets to any symbol of renewal. Thus, the seeds represent hope for growth and renewal after every other hope is gone. Nature represents a stubborn drive for renewal, but is nevertheless unable to save the characters from their hellish existence. The seeds could, in a different context, be seen to represent real renewal, like the regenerating water-symbols at the end of The Waste Land. However, it would be misleading to see any real reconciliation in Death of a Salesman, either between Biff and Willy, or in nature. The only catharsis is when Biff begins to cry and Willy, for a brief moment, understands that his son actually loves him.

17 A. Miller, Death of a Salesman, London: Penguin Classics, 2000, 96. 